\title{
Study of Doppler waveforms in pregnancy induced hypertension and its correlation with perinatal outcome
}

\author{
Smitha K*, Sowmya K, Malathi T \\ Department of Obstetrics \& Gynaecology, Kempegowda Institute of Medical Sciences, V.V. Puram, Bangalore, \\ Karnataka, India
}

Received: 9 May 2014

Accepted: 23 May 2014

*Correspondence:

Dr. Smitha K,

E-mail: smithakeshava@gmail.com

(C) 2014 Smitha $\mathrm{K}$ et al. This is an open-access article distributed under the terms of the Creative Commons Attribution Non-Commercial License, which permits unrestricted non-commercial use, distribution, and reproduction in any medium, provided the original work is properly cited.

\begin{abstract}
Background: Objectives of current study were to study the significance of Doppler in PIH using middle cerebral artery and umbilical artery blood flow and to analyze the role of Doppler in PIH in predicting perinatal outcome.

Methods: Hundred cases of women with pregnancy induced hypertension between 28-40 weeks of gestation were studied for umbilical artery and middle cerebral artery Doppler waveforms. The perinatal outcome results were documented and analyzed statistically using percentage and Chi-square test.

Results: Adverse perinatal outcome was significantly associated with oligohydramnios $(\mathrm{P}<0.0001)$ and grade 3 placental maturity $(\mathrm{P}<0.01)$. Absent end diastolic flow waveform in umbilical artery was associated with mortality of $27.78 \%$ and reverse end diastolic waveform with mortality of $100 \%$. UA PI has the highest sensitivity (88.88\%) and positive predictive value $(69.56 \%)$ in predicting low birth weight. Cerebroplacental ratio (MCA/UA) had highest sensitivity (94.42\%), PPV (86.42\%), accuracy (90\%) for predicting adverse perinatal outcome than UAPI and MCA PI. MCA PI had low specificity in predicting adverse perinatal outcome.

Conclusions: Pregnancy induced hypertension is associated with significant fetal morbidity and mortality. Oligohydramnios in PIH patients is associated with adverse pregnancy outcome. Presence of absent end diastolic flow and reversed end diastolic flow in umbilical artery is an ominous sign with high perinatal mortality. Reversed end diastolic flow is more ominous than absent end diastolic flow. Cerebroplacental ratio (MCA/UA PI) is a better predictor of adverse perinatal outcome, with highest diagnostic accuracy, sensitivity, and positive predictive value, than either vessel Doppler indices considered alone. Colour Doppler study is a simple, quick, non-invasive procedure and is found to be the most accurate among the other tests for antepartum fetal surveillance.
\end{abstract}

Keywords: Umbilical artery Doppler, Middle cerebral artery Doppler, Cerebroplacental ratio, IUGR, Absent end diastolic flow, Reversed end diastolic flow, Perinatal outcome

\section{INTRODUCTION}

Hypertensive disorders complicating pregnancy are common and form one of the deadly triad, along with hemorrhage and infection, that contribute greatly to maternal morbidity and mortality. The incidence of various hypertensive disorder of pregnancy varies widely from 5 to $15 \%$ throughout the globe. It accounts for a total of $7-10 \%$ of perinatal mortality in developed countries and $20 \%$ in developing countries. The perinatal mortality is 5\% in mild PIH and 15 to $25 \%$ in severe PIH.
Satisfactory development of uteroplacental and fetoplacental circulation is necessary for a normal pregnancy outcome. Alternative in its development can be associated with hypertension during pregnancy, which can lead to impaired circulation causing prematurity, subnormal growth (IUGR) or fetal death.

Doppler ultrasound velocimetry provides a non-invasive method of measuring changes in blood flow in the uteroplacental circulation and fetoplacental circulation, thus assessing fetal wellbeing. ${ }^{1}$ 
Management protocols for women with PIH include frequent prenatal visits with ultrasound and fetal heart monitoring. Ultrasound biometry helps to identify a heterogeneous group of small for gestational age fetuses. With the use of Doppler velocimetry, correct detection of compromised IUGR fetus is possible, which allows for timely intervention to improve perinatal outcome. ${ }^{2}$ Evidence from randomized trials suggest that, if women with suspected intrauterine growth restriction and preeclampsia are offered Doppler studies of the umbilical artery, a clinically significant reduction in perinatal mortality may be expected. It has also been suggested that screening of low risk women is not cost effective and also no significant improvement was observed in perinatal outcome. ${ }^{3}$

\section{Aims and objectives}

1. To study the significance of Doppler in pregnancy induced hypertension using middle cerebral artery and umbilical artery blood flow.

2. To analyze the role of Doppler in predicting perinatal outcome.

\section{METHODS}

\section{Source of data}

Patients with pregnancy induced hypertension who attend antenatal clinic and admitted to antenatal ward at KIMS, Bangalore in various units of obstetrics and gynaecology between January 2012 and December2013.

\section{Inclusion criteria}

All pregnant women with PIH between 28-40 weeks of gestation.

\section{Exclusion criteria}

Multiple pregnancy, hydramnios, vesicular mole, pregnant women with hypertension due to other medical conditions like chronic hypertension, renal disorder, diabetes mellitus and other chronic disorders.

\section{Method of collection of data}

Hundred cases of women with pregnancy induced hypertension were studied after applying exclusion criteria patients with pregnancy induced hypertension between 28-40 weeks of gestation were subjected to investigations for PIH. The patients were explained the non-invasive atraumatic nature of the procedure. Initially routine obstetric scan was performed. Doppler wave form patterns of umbilical and middle cerebral arteries were obtained. Patients were followed up till delivery and perinatal outcome was also studied. Examination was performed with the patient in supine position with slight left lateral tilt. The wave forms were obtained during fetal inactivity and apnoea. Umbilical artery Doppler flow velocity waveform was obtained from a free loop of cord and measurements taken when a clear waveform was acquired. The pulsatility index was measured and the presence or absence of end diastolic frequencies was noted. The PI was used as it continues to reflect changes in resistance with progressive absence of end diastolic frequencies or reverse flow, and the values are normally distributed in third trimester. For MCA Doppler US, a transverse image of the fetal head was obtained at the level of the sphenoid bones. Color flow imaging was used to display the circle of Willis. The MCA in the near field was insonated about $1 \mathrm{~cm}$ distal to origin from the internal carotid artery.

The UA pulsatility index ratios were considered abnormal if the value was above the $95^{\text {th }}$ percentile of previously published values for gestational age $\mathrm{and}^{4}$ and MCA pulsatility index ratios were considered abnormal if the value was below the 5 th percentile of previously published values for gestational age. ${ }^{4}$

The MCA/UA PI ratio (Cerebroplacental ratio) is usually constant during the last 10 weeks of gestation. It is possible to use a single cut off value after $30^{\text {th }}$ week as reported by Wladimiroff et $\mathrm{al}^{9}$ who observed no significant differences in cerebroplacental ratio after 26 weeks, Arbeille et $\mathrm{al}^{10}$ also found the cerebroplacental ratio constant during the pregnancy and suggested 1 as the cut off value; all values below 1 were considered abnormal. Gramellini et $\mathrm{al}^{6}$ also used a single cut off value of 1.08 . Therefore in our study a single cut off value (1.08) was used above which velocimetry was considered normal and below which it was considered abnormal.

\section{Outcome criteria}

Adverse perinatal outcome was defined as the presence of any of the following:

1. Emergency cesarean delivery for fetal distress.

2. 5 minute Apgar score of less than $<7$.

3. Admission to NICU.

\section{Perinatal death/IUD.}

Pregnancy outcome was considered to be uneventful or favorable when the above complications were absent. The outcome for each pregnancy was obtained by examining the labour ward records and NICU records.

\section{Statistical methods ${ }^{11}$}

The results were analyzed statistically using Chi-square and Fisher exact test. Diagnostic statistics namely, sensitivity, specificity, PPV, NPV and accuracy were calculated to find the diagnostic value of ultrasound and 
Doppler findings to diagnose the adverse pregnancy outcome.

\section{RESULTS}

100 cases of women with PIH were studied between January 2012 to December 2013.

Table 1: Age distribution.

\begin{tabular}{|lll|}
\hline Age in years & Number & $\%$ \\
\hline$\leq 20$ & 20 & 20.0 \\
\hline $21-25$ & 58 & 58.0 \\
\hline $26-30$ & 21 & 21.0 \\
\hline$\geq 30$ & 1 & 1.0 \\
\hline & $23.41 \pm 3.1$ \\
\hline
\end{tabular}

Table 2: Gestational age.

\begin{tabular}{|lll|}
\hline Gestational age & Number & $\%$ \\
\hline$<37$ weeks & 96 & 96.0 \\
\hline$\geq 37$ weeks & 4 & 4.0 \\
\hline
\end{tabular}

Table 3: Severity of PIH.

\begin{tabular}{|lll|}
\hline PIH & Number & $\%$ \\
\hline Severe PIH & 62 & 62.0 \\
\hline Mild PIH & 38 & 38.0 \\
\hline
\end{tabular}

Table 4: Adverse outcomes.

\begin{tabular}{|lll|}
\hline Adverse outcome & $\begin{array}{l}\text { Number } \\
(\mathbf{n}=\mathbf{4 6})\end{array}$ & $\%$ \\
\hline Low APGAR & 16 & 34.7 \\
\hline NICU admission & 21 & 45.65 \\
\hline Caesarean section & 21 & 45.65 \\
\hline IUD & 10 & 21.74 \\
\hline Perinatal death & 3 & 6.52 \\
\hline
\end{tabular}

Pregnancy outcome was abnormal in 46 patients. More than one adverse outcome observed in some cases $(n=23)$.

Table 5: Mode of delivery.

\begin{tabular}{|lll|}
\hline Mode of delivery & Number & $\%$ \\
\hline Spontaneous & 30 & 30.0 \\
\hline Induction & 43 & 43.0 \\
\hline C section & 27 & 27.0 \\
\hline All cases & 100 & 100.0 \\
\hline
\end{tabular}

Table 6: Association of amniotic fluid with pregnancy outcome.

\begin{tabular}{|llllll|}
\hline \multirow{2}{*}{$\begin{array}{l}\text { Amniotic } \\
\text { fluid }\end{array}$} & \multicolumn{4}{l}{$\begin{array}{l}\text { Pregnancy outcome } \\
\text { Normal }\end{array}$} & \multicolumn{4}{l|}{ Abnormal } & Total \\
\cline { 2 - 6 } & Number & $\%$ & Number & $\%$ & Number \\
\hline Normal & 22 & 91.67 & 2 & 8.33 & 24 \\
\hline Abnormal & 28 & 36.84 & 48 & 63.16 & 76 \\
\hline Total & 50 & 50.0 & 50 & 50.0 & 100 \\
\hline \multirow{2}{*}{ Inference } & $\begin{array}{l}\text { Abnormal amniotic fluid is significantly related to } \\
\text { the abnormal pregnancy outcome with P }<0.0001 * *\end{array}$ \\
\hline
\end{tabular}

Table 7: Association of Doppler findings with pregnancy outcome.

\begin{tabular}{|llcccl|}
\hline \multirow{2}{*}{$\begin{array}{l}\text { Doppler } \\
\text { findings }\end{array}$} & \multicolumn{2}{l}{ Noregnancy } & \multicolumn{2}{l|}{ Abnormal } & Total \\
\cline { 2 - 6 } & No. & $\%$ & No. & $\%$ & No. \\
\hline $\begin{array}{l}\text { MCA-PI } \\
\text { (Abnormal) }\end{array}$ & 26 & 38.24 & 42 & 61.76 & 76 \\
\hline $\begin{array}{l}\text { UA-PI } \\
\text { (Abnormal) }\end{array}$ & 8 & 16 & 42 & 84 & 45 \\
\hline $\begin{array}{l}\text { MCA/UA } \\
\text { (Abnormal) }\end{array}$ & 7 & 12.73 & 48 & 87.27 & 58 \\
\hline AEDF/REDF & - & - & 26 & 100.0 & 26 \\
\hline
\end{tabular}

Table 8: Association of UA Doppler with birth weight.

\begin{tabular}{|llllll|}
\hline UA-PI & $\begin{array}{l}\text { Birth weight } \\
\text { Normal } \\
(>2.5 \mathrm{~kg})\end{array}$ & $\begin{array}{l}\text { Low birth } \\
(<2.5 \mathrm{~kg})\end{array}$ & Total \\
& Number & $\%$ & Number & $\%$ & Number \\
\hline Normal & 32 & 69.57 & 14 & 30.43 & 46 \\
\hline Abnormal & 4 & 7.4 & 50 & 92.60 & 54 \\
\hline Total & 36 & 36.0 & 64 & 64.0 & 100 \\
\hline Inference & $\begin{array}{l}\text { UA-PI is } \\
\text { weight with } \mathrm{P}<0.0001^{* *}\end{array}$ & significantly related & to the & low Birth \\
\hline
\end{tabular}

Table 9: Association of $\mathrm{C} / \mathrm{P}$ ratio with birth weight.

\begin{tabular}{|llllll|}
\hline \multirow{5}{*}{ MCA/UA } & $\begin{array}{l}\text { Birth weight } \\
\text { Normal } \\
(>2.5 \mathrm{~kg})\end{array}$ & $\begin{array}{l}\text { Low birth } \\
(<2.5 \mathrm{~kg})\end{array}$ & Total \\
& Number & $\%$ & Number & $\%$ & Number \\
\hline Normal & 24 & 57.14 & 18 & 42.86 & 42 \\
\hline Abnormal & 12 & 20.68 & 46 & 79.32 & 58 \\
\hline Total & 36 & 36.0 & 64 & 64.0 & 100 \\
\hline Inference & $\begin{array}{l}\text { MCA/UA is significantly related to the low Birth } \\
\text { weight with P<0.0001** }\end{array}$ \\
\hline
\end{tabular}


Table 10: Diagnostics value of Doppler findings for low birth weight.

\begin{tabular}{|lllllll|}
\hline $\begin{array}{l}\text { Doppler } \\
\text { findlings }\end{array}$ & Low birth weight $(<2.5 \mathrm{~kg})$ & & & \\
\hline MCA- PI & 38.88 & 71.87 & 43.75 & 67.64 & 60 & $>0.05$ \\
\hline UA-PI & 88.88 & 78.12 & 69.56 & 92.59 & 92 & $<0.0001$ \\
\hline MCA/UA & 66.66 & 71.87 & 57.14 & 79.31 & 70 & $<0.0001$ \\
\hline
\end{tabular}

Table 11: Diagnostics value of Doppler findings for adverse pregnancy outcome.

\begin{tabular}{|lllllll|}
\hline $\begin{array}{l}\text { Doppler } \\
\text { findings }\end{array}$ & Adverse Pregnancy outcome & & & \\
\hline MCA- PI & 86.24 & 50.63 & 62.23 & 80.24 & 64 & $<0.05$ \\
\hline UA-PI & 90.26 & 80.57 & 82.24 & 88.35 & 84 & $<0.001$ \\
\hline MCA/UA & 94.42 & 82.65 & 86.42 & 96.41 & 90 & $<0.001$ \\
\hline
\end{tabular}

Table 12: Association of absent EDF/Reverse EDF with mortality.

\begin{tabular}{|lllc|}
\hline $\begin{array}{l}\text { Spectral } \\
\text { characteristics }\end{array}$ & $\begin{array}{l}\text { Number } \\
\text { of cases }\end{array}$ & $\begin{array}{l}\text { IUD/Perinatal } \\
\text { mortality }\end{array}$ & $\%$ \\
\hline Absent EDF & 18 & 5 & $27.78 \%$ \\
\hline Reverse EDF & 8 & 8 & $100 \%$ \\
\hline Inference & $\begin{array}{l}\text { Incidence of mortality is higher with } \\
\text { reverse EDF with P is }<0.05 * *\end{array}$ \\
\hline
\end{tabular}

Table 13: Association of amniotic fluid with pregnancy outcome.

\begin{tabular}{|llllll|}
\hline \multirow{2}{*}{$\begin{array}{l}\text { Amniotic } \\
\text { fluid }\end{array}$} & \multicolumn{4}{l}{$\begin{array}{l}\text { Pregnancy } \\
\text { Noutcome }\end{array}$} & \multicolumn{4}{l|}{ Total } \\
\cline { 2 - 6 } & Number & $\%$ & Number & $\%$ & Number \\
\hline Normal & 22 & 91.67 & 2 & 8.33 & 24 \\
\hline Abnormal & 28 & 36.84 & 48 & 63.16 & 76 \\
\hline Total & 50 & 50.0 & 50 & 50.0 & 100 \\
\hline \multirow{2}{*}{ Inference } & $\begin{array}{l}\text { Abnormal amniotic fluid is significantly related to } \\
\text { the abnormal pregnancy outcome with P }<0.0001 * *\end{array}$ \\
\hline
\end{tabular}

\section{DISCUSSION}

In patients with preeclampsia due to inadequate trophoblastic invasion of the maternal spiral arterioles there is abnormal placentation. This in turn causes increased vascular resistance in uteroplacental circulation and decreased perfusion, resulting in increased incidence of IUGR, fetal hypoxia and perinatal death.

Several investigators like Gramellini et al ${ }^{6}$ Berkowitz et al and Fairlie et $\mathrm{al}^{8}$ have demonstrated the correlation between abnormal Doppler indices of fetal vessels and adverse perinatal outcome and fetal distress. Yoon BH et al demonstrated that an abnormal umbilical artery Doppler waveform is a strong and independent predictor of adverse perinatal outcome in patients with preeclampsia. ${ }^{12}$ Mari G et al, have suggested that cerebral Doppler indices are associated with adverse perinatal outcome, while others like Gramellini et $\mathrm{al}^{6}$ and Ozeren
$\mathrm{M}$ et $\mathrm{al}{ }^{14}$ have proposed the cerebral-umbilical ratio as a better predictor of adverse perinatal outcome.

In our study we studied umbilical artery PI, middle cerebral artery PI and MCA/UA PI ratio, a Doppler index that reflects both umbilical-placental and cerebral vascular beds for identifying compromised fetus.

It is important that the intra cranial artery be identified precisely and with certainty as PI varies in relation to the intra cranial artery considered, so in the evaluation of fetal cerebral circulation we used middle cerebral artery, as it is most accessible vessel and it can be easily located on color Doppler. It is the branch of the circle of Willis and carries $80 \%$ of the blood flow to the ipsilateral cerebral hemisphere, a constant $3-7 \%$ of cardiac output flows through it, during entire gestational period.

It is difficult to define normal and abnormal umbilical flow velocity before $30^{\text {th }}$ week, except the absent EDFV after 20 weeks. Therefore we studied the Doppler indices of umbilical artery only after $30^{\text {th }}$ week in agreement with Schulman ${ }^{13}$ and Gramellini. ${ }^{6}$

Wladimiroff et $\mathrm{al}^{9}$ reported that $\mathrm{CP}$ ratio does not vary significantly between 30 and 40 weeks of gestation Hence it is possible to use a single cut off value for CP ratio after 30 weeks. Arbeille et al ${ }^{10}$ also found $\mathrm{CP}$ ratio to be constant during last 10 weeks of gestation and suggested a cut off value of 1.08 above which values are considered normal and below 1.08 values are abnormal.

In our study incidence of perinatal death/IUD, emergency LSCS for fetal distress, NICU admission and low Apgar score at $5 \mathrm{~min}$ were the criteria for adverse perinatal outcome, in concurrence with previous studies.

In the literature the criteria for cerebral redistribution vary, including MCA PI below the $5^{\text {th }}$ percentile, ${ }^{5}$ MCA pulsatility index below 2SD, UA/MCA pulsatility index ratio above $95^{\text {th }}$ percentile, ${ }^{5}$ UA/MCA resistance index above 1.0, MCA/UA RI ratio below 1.0 and MCA/UA 
ratio of less than $1.08 .^{6}$ Comparison between different studies would be more meaningful if uniform or standardized criteria are used.

In present study of 100 cases, $46 \%$ had an adverse perinatal outcome, 68 patients had an abnormal MCA PI out of which $42(61.76 \%)$ had at least one adverse perinatal outcome and others had normal outcome. 50 patients had abnormal UA PI $\left(95^{\text {th }}\right.$ Centile) out of which $42(84 \%)$ developed at least one adverse outcome. Abnormal MCA/UA PI ratio was seen in 55 patients of which $48(87.27 \%)$ had an adverse perinatal outcome.

\section{Cerebroplacental ratio}

In present study the MCA/UA pulsatility index ratio has high sensitivity and positive predictive value, $94.42 \%$ and $86.42 \%$ respectively, in predicting adverse perinatal outcome, compared to that of UA pulsatility index and MCA pulsatility index.

Table 14: Comparison of $\mathrm{CP}$ ratio in predicting adverse perinatal outcome.

\begin{tabular}{|lclll|}
\hline Study (year) & Sensitivity & Specificity & PPV & NPV \\
\hline $\begin{array}{l}\text { Gramellini et } \\
\text { al. }\end{array}$ (1992) & $68.0 \%$ & $98.4 \%$ & $94.4 \%$ & $88.8 \%$ \\
\hline $\begin{array}{l}\text { Fong KW et } \\
\text { al. }^{15}(1999)\end{array}$ & $51.3 \%$ & $80.6 \%$ & $48.1 \%$ & $82.5 \%$ \\
\hline $\begin{array}{l}\text { Ozeren et } \\
\text { al. }\end{array}{ }^{14}$ (1999) & $81.0 \%$ & $89.0 \%$ & $84.0 \%$ & $86.0 \%$ \\
\hline Present study & $94.42 \%$ & $82.65 \%$ & $86.42 \%$ & $96.41 \%$ \\
\hline
\end{tabular}

Our study is comparable with that of Ozeren et $\mathrm{al}^{14}$ and Gramellini et $\mathrm{al}^{6}$ who also concluded that $\mathrm{CP}$ ratio had higher sensitivity and positive predictive value compared to MCA/PI and UA PI.

Present study is not correlating with Fong KW et al ${ }^{15}$ who showed a sensitivity and PPV of $51.3 \%$ and $48.1 \%$ respectively, the difference may be because they included small for gestational age cases in there study.

\section{Umbilical artery pulsatility index}

In present study, the UA PI had sensitivity and positive predictive value of $90.26 \%$ and $82.24 \%$ respectively.

Our findings are comparable with that of Yoon et al, ${ }^{12}$ Gramellini et $\mathrm{al}^{6}$ and Ozeren et al, ${ }^{14}$ they concluded that abnormal umbilical artery Doppler is a strong and independent factor for predicting adverse perinatal outcome in women with PIH.

Present study is not correlating with Gutierrez et al ${ }^{16}$ who showed a sensitivity of $44.0 \%$. The difference may be because they used Doppler ultrasonography profile which included amniotic fluid volume, fetal movements, placental grading, and fetal growth pattern along with umbilical artery velocimetry.
Table 15: Comparison of UA-PI in predicting adverse perinatal outcome.

\begin{tabular}{|lclll|}
\hline Study (year) & Sensitivity & Specificity & PPV & NPV \\
\hline $\begin{array}{l}\text { Gramellini et } \\
\text { al. }^{6}(1992)\end{array}$ & $68.9 \%$ & $98.4 \%$ & $94.4 \%$ & $88.8 \%$ \\
\hline $\begin{array}{l}\text { Yoon et al. } \\
(1994)\end{array}$ & $89.0 \%$ & $86.0 \%$ & $86.0 \%$ & $89.0 \%$ \\
\hline $\begin{array}{l}\text { Ozeren et } \\
\text { al. }^{14}(1999)\end{array}$ & $69.0 \%$ & $97.0 \%$ & $95.0 \%$ & $81.0 \%$ \\
\hline $\begin{array}{l}\text { Gutierrez et } \\
\text { al. }^{16}(2001)\end{array}$ & $44.0 \%$ & $99.0 \%$ & $80.0 \%$ & $97.0 \%$ \\
\hline Present study & $90.26 \%$ & $80.57 \%$ & $82.24 \%$ & $88.35 \%$ \\
\hline
\end{tabular}

\section{Comparison of diagnostic accuracy}

Our study shows highest diagnostic accuracy for CP ratio, followed by umbilical artery pulsatility index and least for middle cerebral artery pulsatility index.

Table 16: Comparison of diagnostic accuracy.

\begin{tabular}{|lll|l|}
\hline $\begin{array}{l}\text { Doppler } \\
\text { index }\end{array}$ & $\begin{array}{l}\text { Gramellini } \\
\text { et al. }\end{array}$ (1992) & $\begin{array}{l}\text { Ozeren et } \\
\text { al. }^{\mathbf{1 4}}(\mathbf{1 9 9 9})\end{array}$ & $\begin{array}{l}\text { Present } \\
\text { study }\end{array}$ \\
\hline CP ratio & $90.0 \%$ & $85.0 \%$ & $90.0 \%$ \\
\hline UA PI & $83.3 \%$ & $85.0 \%$ & $84.0 \%$ \\
\hline MCA PI & $78.8 \%$ & $58.0 \%$ & $64.0 \%$ \\
\hline
\end{tabular}

Our study is comparable with that of Ozeren et $\mathrm{al}^{14}$ and Gramellini et al. ${ }^{6}$

\section{Absent and reverse diastolic flow in umbilical artery}

In our study of 100 cases there were 10 IUDs and 3 perinatal deaths. Out of which 8 had reverse end diastolic flow and 5 had absent end diastolic flow. A mortality rate of $27.78 \%$ in cases of AEDF and $100 \%$ in cases of REDF was observed.

Table 17: Comparison of mortality with REDF and AEDF.

\begin{tabular}{|lll|}
\hline Study (year) & $\begin{array}{l}\text { Mortality in } \\
\%(\text { AEDF) }\end{array}$ & $\begin{array}{l}\text { Mortality in } \\
\% \text { (REDF) }\end{array}$ \\
\hline Mandruzzato et al. $^{17}(1991)$ & - & $63.6 \%$ \\
\hline Failrlie et al. $^{8}(1991)$ & $43.0 \%$ & - \\
\hline Eronen et al. $^{18}(1993)$ & $30.0 \%$ & - \\
\hline Yoon et al. $^{12}(1994)$ & $36.0 \%$ & - \\
\hline Karsdrop et al. $^{19}(1994)$ & $41.0 \%$ & $75.0 \%$ \\
\hline Chauhan et al. & \\
\hline Present study & $260.0 \%$ & - \\
\hline
\end{tabular}

Our results correlate with that of Chauhan et al, ${ }^{20}$ Yoon, Fairlie $^{8}$ and Eronen ${ }^{18}$ et al. The difference seen between our study and Mandruzzato et $\mathrm{al}^{17}$ and Karsdrop ${ }^{19}$ et al study may be because of better perinatal care available in their setup. 


\section{ACKNOWLEDGEMENTS}

We would like to thank our head of the department, Dr. Nirmala Shivalingaiah for her valuable support and advice. We would like to thank the department of radiology and obstetrics and gynaecology for providing the infrastructure required to conduct this study. We would like to sincerely thank all the patients who participated in the study as without them, nothing would be possible.

Funding: No funding sources Conflict of interest: None declared

Ethical approval: Not required

\section{REFERENCES}

1. Carroll BA. Duplex Doppler systems in obstetric ultrasound. Radiol Clin N Am. 1990 Jan; 25(1):189202.

2. Divon MY, Ferber A. Doppler evaluation of the fetus. Clin Obstet Gynaecol. 1992;45(4):1015-25.

3. Alferevic Z, Neilson JP. Doppler ultrasound for fetal assessment in high risk pregnancies. Cochrane Database Syst Rev. 2000;(2):CD000073.

4. Harrington K, Carpenter RG, Nguyen $M$ et al. Changes observed in Doppler studies of the fetal circulation in pregnancies complicated by preeclampsia or the delivery of a small for gestational age baby. I cross sectional analysis. Ultrasound Obstet Gynaecol. 1995;6(1):19-28.

5. Arduini D, Rizzo G. Prediction of fetal outcome in small for gestational age fetus; comparison of Doppler measurements obtained from different fetal vessels. J Perinat Med. 1992;20(1):29-38.

6. Gramellini D, folic MC, Raboni S, Vadora E, Merialdi A. Cerebral-umbilical Doppler ration as a predictor of adverse perinatal outcome. Obstet Gynaecol. 1992;79:416-20.

7. Berkowitz GS, Mehalek KE, Chitkara U et al. Doppler umbilical velocimetry in the prediction of adverse outcome in pregnancies at risk for intrauterine growth retardation. Obstet Gynaecol. 1988;71:742-6.

8. Fairlie FM, More HM, Walker JJ et al. Determinants of perinatal outcome in pregnancy induced hypertension with absence of umbilical artery end diastolic frequencies. Am J Obstet Gynaecol. 1991;164:1084-9.

9. Wladimiroff JW, Wijngaard JAGW, Degani S, Noordam MJ, Eyck J, Tong HM. Cerebral umbilical artery blood flow velocity wave forms in normal and growth retarded pregnancies. Obstet Gynaecol. 1987;69:705-9.
10. Arbeille PH, Trauquant F, Body G et al. Evolution de la circulation arterielle ombilicale et cerebrale du fetus au cours de la grossesse. In: Arbeille PH, Trauquant F, Body G, eds. Progres en Neonatologie. $1^{\text {st }}$ ed. Basel: Karger Editions; 1996: 30-37.

11. M. Venkataswamy Reddy. Statistics for mental health care research. In: M. Venkataswamy Reddy, eds. NIMHANS. India: NIMHANS Publication; 2002.

12. Yoon BH, Lee MC, Kim SW. An abnormal umbilical artery waveform: a strong and independent predictor of adverse perinatal outcome in patients with preeclampsia. Am J Obstet Gynaecol. 1994;171:713-21.

13. Schulman H. Doppler velocimetry of the umbilical and uteroplacental circulation: a critical review. Echocardiogr. 1990;7:583-7.

14. Ozeren M, Dinc H, Ekmen U, Senakayli C, Aydemir V. Umbilical and middle cerebral artery Doppler indices in patients with preeclampsia. Eur J Obstet Gynaecol Reprod Biol. 1999;82(1):11-6.

15. Fong $\mathrm{KW}$, Ohlsson A, Hannah ME, Grisaru S, Kingdom J, Ryan M et al. Prediction of perinatal outcome in fetuses suspected to have intrauterine growth restriction: Doppler US study of fetal cerebral, renal, and umbilical arteries. Radiol. 1999;213:681-9.

16. Gutierrez RG, Barajas AI, Curiel CA, Ponce de Leon PAL. Prediction of fetal wellbeing with Doppler flowmetric profile in pregnant hypertensive women. Gynaecol Obstet Mex. 2001;69:460-6.

17. Mandruzzato GP, Bogatti P, Fischer L, Gigli C. The clinical significance of absent or reverse end diastolic flow in the fetal aorta and umbilical artery. Ultrasound Obstet Gynaecol.1991;1(3):192-6.

18. Eronen M, Kari A, Pesonen E, Kaaja R, Wallgren EI, Hallman N. Value of absent or retrograde end diastolic flow in fetal aorta and umbilical artery as a predictor of perinatal outcome in pregnancy induced hypertension. Acta Paediatr. 1993;82(11):919-24.

19. Karsdorp VH, van Vugt JM, van Geijn HP, Kostense PJ, Arduini D, Montenegro N, Clinical significance of absent or reversed end diastolic velocity waveforms in umbilical artery. Lancet. 1994 Dec;344(8938):1664-8.

20. Chauhan SP, Reynolds D, Cole J, Scardo JA, Magann F, Wax J, Morrison JC. Absent or reversed end diastolic flow in the umbilical artery; outcome at a community hospital. J Miss State Med Assoc. 2005;46(6):163-8.

DOI: $10.5455 / 2320-1770 . i j \operatorname{cog} 20140629$

Cite this article as: Smitha K, Sowmya K, Malathi

T. Study of Doppler waveforms in pregnancy induced hypertension and its correlation with perinatal outcome. Int J Reprod Contracept Obstet Gynecol 2014;3:428-33. 